\title{
URGENSI TEORI KONSELING DAN PERSPEKTIFNYA DALAM ISLAM MENJAWAB TUNTUTAN KONSELING RELIGIUS DI MASA DEPAN
}

\author{
Amirah Diniaty \\ Dosen Prodi Bimbingan Konseling Fakultas Tarbiyah dan Keguruan UIN Suska Riau \\ E-mail: amirahdaniati@gmail.com
}

\begin{abstract}
Counseling is a 'multi refential' science which is developed from several sciences and other theories. In the theoretical perspective, counseling must not be regarded as certain view of providing assistance process, rather, it is a body of knowledge developed from various sources such as the influences of certain techniques, the rise of a status as well as appreciation of subjective individual element, understanding of human's development and knowledge of society. Counseling process that is not based on theory will mislead councelor and reduce the opportunity to change the client's behavior. Islam regards counseling as a virtue as many verses of the Quran and Prophet Tradition (Hadith) discuss the practice of counseling. It is important for the counselor to master Islamic teaching approach so that they can fulfil the needs to future religious counseling.
\end{abstract}

Key words: Urgent, Theoretical Counseling, Islamic Perspective, Religious Counseling

\begin{abstract}
Abstrak: Konseling merupakan ilmu yang bersifat „multi referensial“, artinya ilmu dengan rujukan berbagai ilmu dan teori yang lain. Dalam aspek teoritis, konseling seyogyanya tidak dianggap sebagai suatu pandangan khusus tertentu tentang proses pemberian bantuan, tetapi merupakan suatu batang tubuh pengetahuan yang telah dibentuk dari berbagai sumber, seperti penelitian tentang pengaruh teknik-teknik tertentu, peninggian derajat dan penghargaan terhadap unsur-unsur pribadi yang bersifat subjektif, pemahaman tentang perkembangan manusia dan pengetahuan tentang masyarakat. Proses konseling yang tidak didasari oleh teori akan membuat konselor berbuat tanpa arah dan peluang untuk berhasilnya dalam merubah tingkah laku klien menjadi lebih sedikit. Islam sebagai agama memandang konseling sebagai kegiatan ibadah dan banyak ayat-ayat Al Quran serta hadis yang membahas pelaksanaan kegiatan konseling. Menguasai pendekatan Islam dalam teori konseling diperlukan agar konselor dapat menjawab tuntutan akan konseling relegius di masa depan.
\end{abstract}

Kata kunci : Urgensi, Teori Konseling, Perspektif Islam, Konseling Religius

\section{PENDAHULUAN}

Pernah ada sebuah pameo yang mengatakan, "ah teori". Seringkali teori disalahartikan sebagai formalitas keilmuan yang pada Kenyataannya bertolak belakang dengan praktek atau realitas. Kita pahami asalnya sebuah teori, diawali dari adanya permasalahan yang harus dipecahkan. Untuk mengatasi, menyelesaikan sebuah permasalahan atau persoalan, kita dituntut memiliki rencana tindakan dan sebuah model atau teori.

Lalu apa sesungguhnya teori itu ? Hansen (1977:16) mengemukakan "A theory is a structure upon which the information central to a solution of a problem can be placed". Artinya teori merupakan suatu pernyataan yang terdiri dari informasi utama atau sentral sebagai solusi dari persoalan yang ditemui. Seiring dengan itu Wolman (1973) dalan Hansen (1977:16) mengemukakan "A theory as a system comprised of emperical data derived from observation and/or experimentation, and of their interpretation". Jadi teori merupakan sebuah sistem hasil perbandingan data yang diperoleh melalui observasi atau eksperimen dengan interpretasinya.

Pendapat lain tentang hakekat teori secara singkat dikemukakan Kaplan (1964) dalam Sarlito Wirawan (2004:5) yaitu "A theory is a 
symbolic construction". Menurut Sarlito Wirawan Sarwono (2004:5) teori merupakan serangkaian hipotesis atau proposisi yang saling berhubungan tentang suatu gejala (fenomena) atau sejumlah gejala. Selanjutnya dijelaskan teori di satu pihak adalah ringkasan fakta-fakta dan dipihak lain merupakan perkiraan tentang implikasi (akibat) dari fakta-fakta tersebut dan kemungkinan hubungan antara fakta-fakta tersebut.

Jadi dapat kita simpulkan bahwa teori merupakan kumpulan informasi, atau hipotesa yang telah teruji yang berisikan cara mengatasi masalah, tentunya pengusung atau yang dapat mengemukakan teori bukan individu sambarangan, melainkan orang yang sudah ahli di bidangnya.

Terkait dengan itu profesi konselor yang merupakan pekerjaan profesional juga memiliki landasan teori yang kuat dalam penyelenggaraan praktek layanannya bagi individu. Bahkan ditegaskan sebuah profesi dikatakan profesional jika bertitik tolak dari teori yang ilmiah.

Oleh sebab itu konselor dan individu yang sedang menyiapkan diri menjalani profesi ini, perlu memahami ciri-ciri sebuah teori yang dikatakan bagus, baik atau patut dipelajari. Hansen (1977:16) mengemukakan ,a theory's ability to help us understand what we are doing; that is, it give us a structure against which we can judge how much progress we are making toward a desired outcome. Jadi kita katakan sebuah teori baik, bila teori itu membuat kita memahami apa yang kita kerjakan, dan memberikan struktur atau aturan hingga kita dapat mengetahui pencapaian hasil dari apa yang kita lakukan, tentunya dari kegiatan pelayanan konseling yang diselenggarakan.

Lebih lanjut Hansen

(1977:20) menguraikan ciri-ciri teori yang baik itu sebagai berikut :

The first requirement is that a theory must be clear. It must be easyly understood and communicable. Second, a good theory is one that is comprehensive. It should not deal with the exception or isolated cases, but rather should be designed to explain a great many event in varios situation. A good theory also needs to be heuristic in nature. A good theory should relate means to the desired outcomes and a final poin concerning a good theory is that it does not simply exist- it is something to be used.

Terkait dengan itu Sarlito Wirawan Sarwono (2004:7) mengemukakan, baik tidaknya suatu teori tidak ditentukan oleh bentuk atau isinya, melainkan ditentukan oleh beberapa norma di bawah ini:

1.

Norma korespondensi (norms of corespon-dence), yaitu seberapa jauh teori itu cocok dengan fakta-fakta yang ada. Semakin cocok teori dengan fakta, semakin baik.

2. Norma koherensi (norms of coherence), yang meliputi dua ukuran sebagai berikut:

a.

seberapa jauh teori itu cocok dengan teori-teori sebelumnya. Ini tidak berarti bahwa suatu teori tidak boleh bertentangan dengan satu atau dua teori sebelumnya. Namun, walaupun teori tersebut bertentangan dengan teoriteori tertentu, suatu teori yang baik masih cocok dengan sejumlah teori lainnya.

b. Kesederhanaan

(simplicity), yaitu teori tersebut sederhana dalam arti tidak rumit, tidak berbelit-belit, mudah di-mengerti. Kesederhanaan ini meliputi 2 hal berikut: 1) kesederhanaan deskriptif, yaitu kesederhanaan dalam uraian tentang teori itu sendiri

2) kesederhanaan induktif, yaitu kesederhanaan dalam prosedur penarikan kesimpulan (induksi) dari data-data yang ada.

3. Norma pragmatik, yaitu seberapa jauh suatu teori mempunyai kegunaan praktis. Semakin besar kegunaan praktisnya, semakin baik teori yang bersangkutan. 
Dalam perkembangannya sebuah teori tidak terbentuk secara statis, tetapi terus berproses. Williamson (1965) dalam Hansen (1977:18) mengemukakan " a true theory is only a provisional formulation of a position or interpretation, which is then subject to some form of verification and testing, and followed by reformulation of theory". Jadi teori itu merupakan hasil formulasi yang dilakukan dengan profesional, yang jika diinterpretasikan serta dapat dicari kejelasan dan diuji subjek tertentunya maka akan menghasilkan teori baru.

Merujuk pada teori di atas, maka kita perlu melihat apa sesunggunya hakekat teori konseling itu? Bagaimana sebaiknya seorang konselor bersikap terhadap teori konseling yang dipelajarinya? Lalu bagaimana perspektif Islam terhadap teori konseling tersebut? Hal ini akan dikaitkan dengan tuntutan konseling religius di masa depan, di mana konselor yang berpegang pada pendekatan agama dalam hal ini agama Islam akan lebih diminati dan diharapkan oleh pengguna jasa yaitu klien. Tuntutan dan tantangan ini perlu dipahami serta disikapi secara bijak. Inilah yang menjadi isi dari tulisan ini.

\section{HAKEKAT DAN ARTI PENTINGNYA TEORI KONSELING}

Pada bagian di atas dijelaskan bahwa teori merupakan rencana tindakan. Teori adalah sebuah model tentang bagaimana berbuat dan batasan-batasan yang mengatur agar apa yang kita lakukan menjadi tepat, sebab teori lahir dari hipotesa yang telah teruji. Lalu kaitannya dengan konseling? Maka dijelaskan teori konseling menurut Hansen (1977:23) adalah:

"Provide a means of organizing what people have learned about the process of counseling. They are designed to serve as guides to indicate possible causes of a client's difficulties, alternative courses of actio, and the desired conselor behavior in the counseling process.

Dengan kata lain, teori konseling merupakan aturan yang disusun sedemikian rupa untuk membantu konselor melakukan proses konseling, sehingga menjadi bahan analisis konselor terhadap kesulitan-kesulitan klien. Adanya teori membuat konselor dapat menentukan tindakan yang tepat.

E.A.Munro (1985:15) menegaskan dalam aspek teoritis, konseling seyogyanya tidak dianggap sebagai suatu pandangan khusus tertentu tentang proses pemberian bantuan, tetapi merupakan suatu batang tubuh pengetahuan yang telah dibentuk dari berbagai sumber, seperti penelitian tentang pengaruh teknik-teknik tertentu, peninggian derajat dan penghargaan terhadap unsur-unsur pribadi yang bersifat subjektif, pemahaman tentang perkembangan manusia dan pengetahuan tentang masyarakat. Dari penjelasan ini, dapat kita pahami bahwa teori konseling bukanlah sebuah paham tertentu dalam mempraktekkan konseling. Teori konseling merupakan dasar ilmu yang tentu sifatnya ilmiah, dapat dipertanggungjawabkan melalui penelitianpenelitian tentang hal-hal yang terkait dengan proses konseling.

Oleh sebab itu, teori konseling dibentuk oleh berbagai latar belakang disiplin ilmu dan tinjauan. Untuk memahami tingkahlaku individu, teori konseling didukung oleh teori kepribadian, konsep-konsep tentang tingkah laku individu. Terkait dengan dasar teori konseling, Prayitno (2002:32) menegaskan konseling merupakan ilmu yang bersifat "multi referensial", artinya ilmu dengan rujukan berbagai ilmu dan teori yang lain. Psikologi, ilmu pendidikan, filsafat memberikan sumbangan yang besar dalam teori konseling Begitu juga biologi, sosiologi, ilmu ekonomi, antropologi, ilmu kemasyarakatan, ilmu hukum, agama, dan adat-istiadat dan ilmu statistik serta evaluasi.

Teori sebagai sebuah dasar atau model yang dapat dijadikan pedoman dalam melakukan suatu tindakan sehingga diperoleh hasil yang lebih baik. Ungkapan tersebut menggambarkan arti pentingnya teori. Lebih rinci Shertzer and Stone (1974) dalam Hansen (1977: 21) mengemukakan fungsi teori yaitu:

(1) A theory serves to synthesize a particular body of knowledge (2) A theory serve to increase the understanding of a particular 
body of knowledge (3) a theory provides the tool by which predictions may be made (4) a theory serve to encourage further research into the area, that it stimulates further investigations into the particular phenomena with which it is concerned.

Jadi teori dapat menjadi bagian yang membentuk ilmu, membantu untuk meningkatkan pemahaman tentang bagian dari ilmu pengetahuan, berfungsi sebagai alat untuk memprediksi apa yang akan dilakukan/dibuat, dan membantu pelaksanaan penelitian. Begitu banyak fungsi atau arti pentingnya teori, sehingga perlu untuk dipelajari sebelum melakukan tindakan atau penelitian.

Terkait dengan teori konseling, E.A. Munro (1985:15) mengemukakan konselor akan memperoleh manfaat yang amat besar dengan mempelajari teori-teori konseling dan oleh karena itu mereka yang sedang mempelajari latihan sebagai konselor perlu mempelajari teori-teori konseling. Dalam mempelajari teoriteori konseling dari awal sampai akhir, calon konselor selalu dihadapkan pada tantangan untuk meresapkan apa yang dikemukakan oleh masing-masing teori itu ke dalam dirinya sendiri sehingga dapat memperkaya khasanah keterampilannya dan memperindah corak pribadi penampilan usaha-usahanya.

Arti penting teori konseling bagi konselor lebih lanjut dijelaskan Hansen (1977:22) bahwa;

A counselor who operates without asking what is happening, without some model of action, or without some assumtions about counseling is not only an unscientific counselor-he is a couselor who is very likely to flail about with little chance of success.

Jadi konselor yang tidak mempelajari teori, disebut bukan saja konselor yang tidak ilmiah, berbuat tanpa model, tanpa asumsi tentang konseling, dia adalah konselor yang gagal. Dengan kata lain proses konseling yang tidak didasari oleh teori akan membuat konselor berbuat tanpa arah dan peluang untuk berhasilnya dalam merubah tingkah laku klien menjadi lebih sedikit.

\section{SIKAP KONSELOR TERHADAP TEORI KONSELING YANG DIPELAJARI}

Teori yang dipelajari konselor akan mewarnai bagaimana dia melaksanakan praktik konseling, dan ini menjadi ciri keprofesionalan konselor dalam menjalankan profesinya. Oleh sebab itu, konselor harus mampu bersikap yang tepat terhadap teori yang dipelajarinya. Prayitno (1998) mengemukakan ada lima tingkatan keprofesionalan konseling yang diselenggarakan yang terlihat sikap konselor yang berbeda-beda terhadap teori yang dipelajarinya; yaitu pragmatik, dogmatik, sinkretik, dan eklektik serta mempribadi.

Pertama, pendekatan pragmatik. Ciri pragmatik akan tampak apabila penyelenggaraan konseling menggunakan cara-cara yang menurut pengalamannya yang terdahulu dianggap memberikan hasil yang optimal, meskipun cara-cara tersebut sama sekali tidak berdasarkan teori tertentu. Praktik pragmatik ini merupakan kenyataan yang paling primitif dalam penyelenggaraan konseling

Kedua, pendekatan dogmatik. Pendekatan atau cara konselor bersikap terhadap teori yang dipelajarinya ini, agak lebih tinggi tingkatannya dari konseling yang pragmatik. Ciri-cirinya, teori konseling tertentu telah digunakan dalam praktek konseling, bahkan teori dijadikan dogma, keyakinan yang dipegang teguh oleh konselor tersebut untuk segenap permasalahan dari semua jenis klien; sepertinya tidak ada teori lain yang dapat dipakai dalam konseling selain teori itu.

Mengenai pendekatan dogmatik, E.A. Munsro (1985:15) menegaskan adalah kurang menguntungkan jika konselor dalam melaksanakan tugas-tugasnya selalu mendasarkan diri dan terikat pada satu teori konseling saja. Teori khusus tertentu yang lebih disukai oleh konselor mempunyai peran yang lebih kecil dibandingkan dengn alasan-alasan dan pertimbangan yang mendasari dugaan dan tindakan konselor terhadap klien. 
Ketiga, pendekatan sinkretik. Konselor telah mengagungkan sejumlah teori untuk penyelenggaraan konseling, namun penggunaannya tercampur, tidak sistematik dan tanpa ada pertimbangan yang matang. Satu teori tepat digunakan kapan dan untuk apa sedangkan teori lain tepat untuk kondisi klien yang berbeda pula, tidak dipertimbangkan oleh konselor yang bersikap sinkretik. Teori-teori yang dipelajari sekedar diambila sana-sini dan dipakai untuk menangani masalah klien tanpa memperhatikan relevansi dan ketepatannya. Jelas ini tidak tepat.

Keempat, pendekatan eklektik. Pada tingkatan ini keprofesional konselor melaksanakan konseling telah lebih tinggi dari tingkat sebelumnya. Penyelenggaraan konseling ditandai dengan pemahaman yang mendalam terhadap teori yang dipelajari dan konselor berusaha memilih, menerapkan sebagian atau satu kesatuan teori yang satu dan yang lainnya beserta teknologinya sesuai dengan kebutuhan dan permasalahan klien. Teori yang dipelajari tidak dicampuradukkan, namun dipilah-pilah sesuai dengan karakteristik klien dan permasalahannya.

Prayitno (1998) menjelaskan lebih tinggi lagi tingkat keprofesionalan konseling adalah jika praktik konseling eklektik diberi warna khas oleh nuansa-nuansa positif yang memancar dari diri pribadi konselor, yang disebut dengan konseling mempribadi. Ciri-cirinya adalah : (a) konselor menguasai sejumlah teori konseling beserta teknologinya secara mendalam (b) mampu memilih dan menerapkan secara tepat teori beserta teknologinya untuk menangani permasalahan klien dan (c) pemberian warna pribadi yang khas sehingga tercipta praktik konseling yang benar-benar ilmiah, tepat guna, produktif dan unik. Konselor yang telah mempribadi, telah mampu menerapkan teori dalam konseling yang dikreasikan dan dimodifikasi sendiri sehingga bisa memunculkan teori baru.

\section{PERSPEKTIF ISLAM TENTANG TEORI KONSELING}

Kata Islam berasal dari bahasa arab assalam yang berarti keselamatan atau kedamaian. Islam adalah agama. Hakekat agama itu sendiri menurut Zakiah Drajat, dkk (1986) adalah risalah yang disampaikan Tuhan kepada Nabi sebagai petunjuk bagi manusia dan hukum-hukum sempurna untuk dipergunakan manusia dalam menyelenggarakan tata cara hidup yang nyata serta mengatur hubungan dengan dan tanggung jawab kepada Allah. Agama adalah sumber sistem nilai yang menjadi petunjuk, pedoman dan pendorong bagi manusia untuk memecahkan berbagai masalah hidupnya.

Lebih jauh dijelaskan agama Islam adalah agama Allah yang disampaikan kepada Nabi Muhammad, untuk diteruskan kepada seluruh ummat manusia, yang mengandung ketentuanketentuan keimanan (aqidah) dan ketentuanketentuan ibadah dan muamalah (syariah), yang menentukan proses berfikir, merasa dan berbuat dan proses terbentuknya kata hati. Dengan demikian dapat diuraikan tiga unsur penting dalam Agama Islam yaitu (dalam Zakiah Darajat, dkk 1986):

1. Iman; keyakinan kepada (a) Allah (b) malaikatnya (c) kitabnya (d) rasulnya (e) hari akhir dan (f) Qadha dan Qadar, yang kita kenal dengan rukun iman.

2. Islam; penyerahan diri sepenuhnya kepada ketentuan Allah yaitu (a) syahadatain (b) shalat (c) zakat (d) puasa (e) haji

3. Ihsan; beraklaq shalih pendekatan (mikro) yang melaksanakan ibadat kepada Allah dan bermuamalah dengan sesama makluk dengan penuh keikhlasan seakan-akan disaksikan oleh Allah, meskipun dia tidak melihat Allah. Adapun muamalah dengan sesama makhluk terdiri dari :

a. Bermuamalah dengan manusia; dalam bentuk

1) hubungan dengan rasul, dengan cara mentaati, meniru, mncintai dan mendoakan/bersalawat

2) menyantuni/membina diri

3) hubungan dengan

4) hubungan dengan masyarakat hubungan dengan bangsa 
6) hubungan

7) antar bangsa

b. Hubungan dengan tumbuhtumbuhan

c. Hubungan dengan hewan

d. Hubungan dengan benda, baik organik maupun anorganik

Berdasarkan penjelasan di atas, maka Islam selalu berorientasi pada kebaikan dan kearah perkembangan yang positif. Lalu jika Islam kita gunakan sebagai kaca mata dalam melihat teori konseling bagaimana?

Konseling dalam perspektif Islam dapat diartikan sebagai bagian dari ibadah atau amal yang harus dilakukan umat muslim untuk mendapatkan kedekatan dengan khaliknya. Konseling sebagai proses membantu individu oleh tenaga profesional yang bernama konselor, agar ia (klien) memahami diri, membuat keputusan dan pemecahan masalah, sebenarnya merupakan suruhan Allah kepada umatNya.

Dalam Surat Al Ashr (ayat 1-3) Allah telah memberikan aba-aba bahwa hidup manusia akan sangat terikat dengan waktu dan sesungguhnya manusia berada dalam kerugian. Allah menegaskan orang yang tidak merugi adalah orang-orang yang beriman dan mengerjakan amal kebajikan, serta saling menasehati supaya menjalankan kebenaran dan saling menasehati supaya tabah menghadapi kesukaran.

Selanjutnya, dalam Islam profil konselor ideal telah diciptakan Allah yaitu nabi Muhammad SAW. Allah berfirman dalam surat al-ahzab: 21:

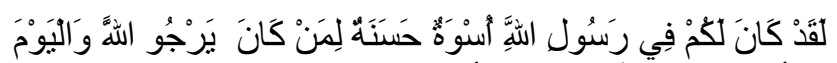

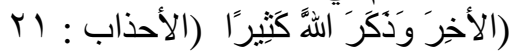

Sesungguhnya telah ada pada diri Rasulullah itu suri teladan yang baik bagimu bagi orang yang mengharap (rahmat) Allah dan (kedatangan) hari kiamat dan dia banyak menyebut Allah.

Ayat-ayat Al Qur'an banyak sekali yang mengandung nilai konseling, namun hal itu belum terungkap dan tersaji secara konseptual dan sistematis. Allah mengisya-ratkan untuk memberikan kemudahan bagi orang yang mau mempelajari ayat-ayat Al Qur'an. Firman AllahSwt. Yang artinya: Sesungguhnya telah Kami mudahkan Al Qur'an untuk pelajaran, maka adakah orang yang mengambil pelajaran? (Q.S. Al-Qamar: 40).

Ayat-ayat Al Qur'an itu mudah dipelajari, memahaminya tidak memerlukan penafsiran yang rumit, serta kandungannya bisa dikaitkan kepada hal-hal yang aktual, karena ayat-ayat $\mathrm{Al}$ Qur'an memang memuat fakta-fakta hukum yang bersifat emperik, sekaligus memuat nilainilai yang bersifat filosofis, sehingga isinya mudah diungkap dan bisa dikaitkan ke berbagai aspek realitas kehidupan.

Jadi dapat kita simpulkan dalam kaca mata Islam konseling merupakan bagian dari ibadah yang dilakukan umat muslim guna mendapatkan amal di sisi Khaliknya Allah SWT. Nabi Muhammad SAW diciptakan Allah sebagai Profil Konselor ideal yang perlu dicontoh oleh konselor muslim. Dan sebenarnya Allah telah mengatur dalam kitab suci Alquran prosedur, teknik dan metode dalam pelaksanaan konseling. Hal penting lainnya dalam kacamata Islam, seorang konselor perlu menguasai nilainilai agama guna membantu klien yang mengalami masalah dan butuh kejelasan, pandangan dari ajaran agama tersebut.

Untuk membahas hal ini, akan diuraikan bagaimana Allah berfirman yang ada dalam $\mathrm{Al}$ Quran tentang hakekat manusia, kepribadian dan perkembangannya serta kasus atau bermasalahnya hidup manusia. Tujuan konseling dan teknik konseling yang termaktub dalam Al Quran akan diuraikan juga (Abdul Hayat, 2008).

1.Hakekat manusia menurut Al-Quran dan Hadits

Menurut kandungan ayat-ayat Al Qur'an manusia itu pada hakekatnya adalah makhluk yang utuh dan sempurna, yaitu sebagai makhuk biologis, pribadi, sosial, dan makhluk religius. Manusia sebagai makhluk religius meliputi ketiga komponen lainnya, yaitu manusia sebagai makhluk biologis, pribadi dan sosial selalu terikat dengan nilai-nilai religius. 
Manusia itu dilahirkan dalam keadaan fitrah, Hadits Riwayat Muslim, artinya : Tiaptiap orang itu dilahirkan ibunya atas dasar fitrah, kedua orang tuanyalah yang menjadikannya Yahudi, Nasrani atau Majusi. Apabila kedua orangtuanya muslim, jadilah ia muslim (H.R. Muslim). Sesuai dengan fitrahnya, bahwa manusia itu dilahirkan dalam keadaan suci, secara fitrah beragama tauhid dan penerima kebenaran (Surat Ar Ruum, 30: 30). Sudah ada perjanjian mengakui Allah sebagai Tuhan (Surah AlA'raf, $7: 172$ ).

Manusia dibekali dengan potensi akal, pendengaran, penglihatan dan hati (Surah Ar Ra'du, 13: 19 - 20; As-Sajadah, 32: 9). Manusia dibekali dengan petunjuk ilahiyah, (Surah Al Fatihah, 1: 7). Potensi lain yang diberikan pada manusia oleh Allah SWT adalah :

a. Manusia diberi kekuatan batin dan keyakinan yang mantap (Al Anfal, 8: 2 -4)

b. Selalu berpikir positif (positivisme), Hadits riwayat Ibnu Asakir Artinya: Bekerjalah untuk kepentingan duniamu seolah-olah kamu akan hidup abadi, dan bekerjalah untuk akhiratmu seolah-olah kamu akan mati esok hari.

c. Dilebihkan dari makhluk lain (Al-Isra', $17: 70)$

d. Dilengkapi dengan indera dan hati agar bersyukur (An-Nahl, 16: 78)

e. Memiliki pandangan hidup yang lurus (Al Bayyinah, $98: 5$ )

f. Termasuk kesabaran dalam menghadapi masalah. Apakah bisa mengambil hikmah dari peristiwa yang sedang dicobakan Allah kepada manusia. Allah akan menguji hambaNya dengan kesenangan, kesusahan, kecemasan, kepedihan, dan kematian. Tergantung seberapa besar tingkat keimanan manusia menerimanya. Kalau manusia bisa menerima dan yakin bahwa dengan cobaan itu Allah akan meninggikan derajat manusia dengan tawakkal.

Manusia diberi kebebasan (Surah Asy Syams, 91: 8). Manusia bertanggung jawab atas perbuatannya (Surah Al-Qiyamah, 75 : 13 - 15; Surah Al Mudatsir, 74 : 38; Surah Al Isra', 17 : 36). Manusia diberi kebebasan untuk menentukan pilihannya sendiri, namun demikian ia tetap bertanggung jawab atas pilihannya itu. Potensi yang diberikan Allah kepada manusia diserahkan sepenuhnya penggunaannya kepada manusia itu sendiri, konsekuensinya nanti harus mempertanggungjawabkan akibat dari perbuatannya itu kepada manusia, alam untuk saat ini dan di sini di dunia, dan kepada Sang Pencipta untuk disana dan yang akan datang di akhirat.

Keberadaan manusia adalah berfungsi sebagai berikut:

a.

Sebagai makhluk Allah, yang secara kodrati merupakan makhluk religius (mengabdi kepada Allah / abdullah).

b. Sebagai makhluk individu, yang memiliki kekhasan masingmasing, memiliki potensi dan eksistensi sendiri. Dengan keunikan yang dimilikinya, menjadikan setiap individu itu berbeda dengan yang lainnya, sehingga manusia dituntut untuk memikirkan keadaan dirinya. (Surah Al Qomar, 54 : 49)

c. Sebagai makhluk sosial, yang memerlukan bantuan dan selalu berhubungan dengan orang lain. Tidak mungkin manusia hidup sendiri tanpa melibatkan pihak lain. Oleh karena itu, ia selalu memikirkan orang lain. (Surah $\mathrm{Al}$ Hujurat, 49 : 13 ). Aturan dalam Al-Quran, sebagai makhluk sosial manusia harus menjaga keseimbangan antara hablu minallah dan hablumminannas (Ali Imran, 3: 112), saling menolong dalam kebajikan dan menjauhi perbuatan yang jelek (Al Maidah, 5: 1-2), saling menasihati dan menaati kebenaran, serta berlaku sabar dan adil ( $\mathrm{Al}$ Ashr, 103: 1-3), memelihara silaturrahim (An Nisa', 4: 1)

d.

Sebagai makhluk berbudaya, yang hidup di dalam dan mengelola alam dunia ini dengan akal dan pikirannya untuk menciptakan kebudayaan. Sebutan khalifah fil ardh sesuai untuk fungsi sebagai pengelola alam dan memakmurkannya. Surah Al Fatir, 35: 39: 
"Dialah yang menjadikan kamu khalifahkhalifah di muka bumi ini”.

Sesuai dengan fungsinya di atas, terdapat empat ragam relasi manusia yang masingmasing memiliki kutub positif dan negatif, yaitu:

a. Hubungan manusia dengan dirinya sendiri (hablu minannas) yang ditandai oleh kesadaran untuk melakukan amal ma'ruf nahi munkar (QS, Ali Imran, 3: 110) atau sebaliknya mengumbar nafsu-nafsu rendah (QS, Yasin, $36: 6$; QS, Al Jatsiyat, $45: 23$ ).

b.

Hubungan antar manusia

(hablum-minannas) dengan usaha membina silaturahmi (QS, An Nisa', 4: 1) atau memutuskannya (QS, Yusuf, 12: 100).

c. Hubungan manusia dengan alam sekitar (hablu minal alam) yang ditandai upaya pelestarian alam dan pemanfaatan alam dengan sebaikbaiknya (QS, Hud, 11: 6) atau sebaliknya menimbulkan kerusakan alam (QS, Ar Ruum, 30: 41).

d. Hubungan manusia dengan Sang Pencipta (hablu minallah) dengan kewajiban ibadah kepadaNya ( QS, Adz Dzaariyat, 51 : 56 ) atau menjadi ingkar dan syirik kepadaNya (QS, An Nisa', 4 : 48).

\section{Kepribadian dan Perkembangannya}

Pembicaraan tentang kepribadian dan perkembangannya dalam al-Quran kita mulai dengn proses penciptaan manusia. Menurut AlGhazali (dalam Netty Hartaty, 2005:104) proses penciptaan manusia memiliki tiga proses yakni:

a. Taswiyah, yakni aktivitas di dalam tempat penerimaan ruh, yaitu tanah (al-thin) bagi Adam dan air mani (al-nuthfah) bagi anak cucunya. Kondisi taswiyah ini bersih dan suci dari segala kotoran

b. Nafkh, yaitu menyulutnya cahaya ruh pada syaraf air mani. Nafkh merupakan citra dan hasil. Citranya adalah seperti mengeluarkan angin dari lambung zat yang meniupkan pada lambung orang yang diberi, sehingga syaraf-syarafnya menyalakan cahaya.

c. Ruh, yaitu substansi yang bukan baru datang (aradh), sebab ia mampu mengenal dirinya sendiri dan penciptanya, serta mampu memahami hal-hal yang masuk akal.

Lebih lanjut dijelaskan, dalam penciptaan ini unsur psiko dan fisik telah inheren ada semenjak kejadian manusia. Setelah benar-benar ia ada di alam realita, maka muncullah potensi ghazirah dalam arti insting, naluri, tabiat, perangai, kejadian laten, ciptaan dan sifat bawaan.

Kepribadian manusia dalam Islam menurut Sukamto (dalam Ramayulis, 2002:104) terdiri dari empat sistem atau aspek yaitu:

a. Qalb (angan-angan kehatian) sebagaimana dalam sebuah hadit Nabi riwayat Bukhari/Muslim berbunyi: "ketahuilah bahwa di dalam tubuh ada sekepal daging. Kalau itu baik, baiklah seluruh tubuh. Kalalu itu rusak, rusaklah seluruh tubuh. Itulah Qalb.

b. Fuad (perasaan/hati nurani/ulu hati) perbedaan Fuad dengan hati adalah dalam situasi yang bagaimanapun tidak bisa dusta. Ia berbicara apa adanya. Hal ini dapat dilihat dalam Surat Anm Najm : 11 artinya "Fuad tidak berdusta tentang apa yang dilihatnya."

c. Ego (aku sebagai pelaksana dari kepribadian dan

d. Tingkah laku (wujud gerakan).

Muhammad Iqbal (dalam Netty Hartaty, 2005:108) berpendapat bahwa setiap manusia merupakan suatu pribadi atau suatu ego yang berdiri sendiri, tetapi belumlah dia menjadi pribadi yang utama. Manusia yang dekat kepada Tuhan adalah yang utama. Sebagaimana difirmankan Allah dalam Al-Quran Surat Al Hujurat ayat 13 yang artinya "... Sesungguhnya orang yang paling mulia di antara kalian di sisi 
Allah adalah yang paling bertakwa di antara kalian".

Sifat kepribadian manusia (dalam Muhammad Utsman Najati, 2005: 375) digambarkan dalam tiga konsep jiwa yaitu ammarah bis su', nafsu lawwa, dan nafsu muthmainnah. Manakala kepribadian manusia berada pada tingkatan insaniah paling rendah ketika hawa nafsu, syahwat dan berbagai kesenangan ragawi dan duniawi menguasai-nya, ia berada dalam kondisi yang sesuai dengan gambaran nafsu ammarah. Sebaliknya ketika kepribadian berada dalam kesempurnaan insaniah ia berpegang pada ketakwaan dan ketaatan pada Allah, mampu menguasai hawa nafsu dan syahwat maka ia sesuai dengan gambaran nafsu muthmainnah.

Antara dua gambaran atau tingkatan kepribadian tersebut, terdapat tingkatan pertengahan. Dalam tingkatan ini seseorang akan melakukan introspeksi atas kesalahan yang diperbuatnya. Ia akan berusaha sekuat tenaga untuk menghindari perbuatan yang dapat mengundang murka Allah dan menimbulkan perasaan menyesal dalam hatinya, tetapi ia selalu gagal dalam usahannya itu. Kadang ia lemah dan terjerembab ke dalam kesalahan. Kepribadian dalam tingkatan ini disebut nafsu lawwamah.

Ibn Qayyim Al-jauziyah (dalam Netty Hartaty, 2005:107) menggambarkan kepribadian mutmainnah dan kepribadian amarah ibarat dua kutub yang berlawanan sebagai berikut: (lihat tabel)

Perkembangan kepribadian manusia dipengaruhi oleh banyak faktor. Iqbal (dalam Netty Hartaty, 2005:109) mengemukakan halhal yang dapat memperkuat pribadi muslim ialah :
a. Isyqa-muhabbat, yakni cinta kasih
b. Toleransi, rasa tenggangmenenggang
c. Faqr yakni tidak mengharapkan imbalan

Sementara hal yang melemahkan pribadi adalah takut, suka meminta-minta, perbudakan dan sombong.

\section{Kasus}

Pribadi sehat menurut Islam berfungsinya iman sebagai penentu dalam kognitif, afektif dan psikomotorik. Dalam hal ini berarti berpikir, bertindak dan berbuat sesuai dengan fitrahnya yang mengarah pada kebahagiaan hidup di dunia dan di akhirat kelak. Pribadi sehat akan mengarahkan manusia kepada mental yang sehat pula. Meliputi mencintai Allah, bertaqwa, mengakui kesalahan, beramar ma'ruf nahi munkar, memelihara hubungan dengan Allah dan dengan sesama manusia, berpandangan hidup lurus, saling menolong dalam kebaikan dan melarang berbuat dosa, batinnya kuat, berlaku sabar dan adil, bernasihat tentang kebenaran, selalu mengingat Allah, menjaga keseimbangan dunia akhirat, selalu berpikir positif, dan menjaga silaturrahim.

Pribadi tidak sehat menurut Islam adalah iman tidak dapat berfungsi penuh sebagai penentu/pengendali dalam kognitif, afektif dan psikomotorik. Pribadi tidak sehat ini dalam Al Qur'an termasuk golongan hamba yang tidak mendapat petunjuk dan tidak dicintai Allah. Mereka itu sesat karena tidak mau menggunakan akalnya.

Hal ini berarti manusia tidak memanfaatkan potensi yang diberikan Allah, melupakan Allah, dzalim, kafir, musyrik, syirik, munafiq, selalu mengikuti hawa nafsu, dan selalu berbuat kerusakan. Kecemasan sebagai suatu kondisi hidup bermasalah diingatkan Allah dalam Al Quran(Ar Ra'du, 13 : 28). Perasaan cemas tarafnya bermacam-macam, mulai dari yang paling ringan sampai yang paling berat. Mulai dari yang sifatnya normal/biasa sampai kecemasan neurotik yang merupakan gejala gangguan kejiwaan. 
321 | Jurnal Al-Ta'lim, Jilid 1, Nomor 4 Februari 2013, hlm. 312-323

\begin{tabular}{|c|c|c|}
\hline No. & Kepribadian muthmainnah & Kepribadian ammarah \\
\hline 1 & Hamiyah (memiliki harga diri) & Jufa' (menjatuhkan harga diri) \\
\hline 2 & Tawadhu'(merendahkan diri) & Mahaat (menghinakan diri) \\
\hline 3 & Jud (dermawan) & Sarf (menghambur-hamburkan harta) \\
\hline 4 & Mahabat (kewibawaan) & Kibr (kesombongan) \\
\hline 5 & Syiyanat (memelihara diri) & Takabbur (menyombongkan diri) \\
\hline 6 & Syaja'at (berani) & Nejad (jar' at) \\
\hline 7 & Huzn (prihatin) & Jubn (penakut) \\
\hline 8 & Iqtishad (ekonomis) & Syukh (pelit) \\
\hline 9 & Ihtiraz (waspada) & Suw al zhan (buruk sangka) \\
\hline 10 & Farasat (firasat) & Zhan (menduga) \\
\hline 11 & Neshihat (memberi peringatan) & Ghibat (menunjukkan keburukan) \\
\hline 12 & Hidayat (memberi hadiyah) & Riswah (menyogok) \\
\hline 13 & Shabr (sabar) & Qawah (keras hati) \\
\hline 14 & Afw (pemaaf) & Zull (hina) \\
\hline 15 & Ma'rifah wa'ilm (mengetahui dan berilmu) & Bawl wa ghafl (bodoh dan lupa) \\
\hline 16 & Siqqat (dapat dipercaya) & Ghurur (penipu) \\
\hline 17 & Raj’ (pengharapan) & Tamanny (angan-angan) \\
\hline 18 & Tahaddus (mencerikatan nikmat Allah) & Fakhar (membangga-banggakan harta) \\
\hline 19 & Riqqah al-galb (hati lembut) & Jaza' (penuh keluh kesah) \\
\hline 20 & Mawjadat (iri hati atas kebaikan) & Hiqd (iri hati atas keburukan) \\
\hline 21 & Munafasar (berlomba demi kebaikan) & Hasad (dengki) \\
\hline 22 & Hubb fi Allah (mencintai Allah) & Hubb ma'a Allah (mencintai karena yg lain) \\
\hline 23 & Tawakkal (menyerahkan diri setelah berusaha & 'ajz (lemah hati) \\
\hline 24 & Ihtiyat (hati-hati) & Was-was (ragu-ragu) \\
\hline 25 & Ilham min malaki (inspirasi dari malaikat) & Ilham min syaitan (insprasi dari setan) \\
\hline 26 & Mubadarah (cekatan dalam bekerja). & 'ajlat (terburu-buru dalam bekerja) \\
\hline
\end{tabular}




\section{Tujuan Konseling}

Tujuan konseling menurut Islam pemberdayaan iman, atau mengembalikan manusia sesuai dengan fitrahnya yaitu beragama tauhid dan penerima kebenaran, terikat pejanjian dengan Allah dan mengakui bar Allah itu Tuhannya, dibekali dengan potensı akal, pendengaran, penglihatan, hati, dan petunjuk Ilahiyah, sebagai khalifah atau pemegang amanat untuk tugas keagamaan, dan sebagai Abdullah (pengabdi), bertanggung jawab atas pebuatannya, serta diberi kebebasan untuk menentukan jalan hidupnya sesuai dengan fitrahnya.

Sesuai dengan nilai-nilai keimanan yang dipegang umat Islam, konseling bertujuan menanamkan nilai-nilai tersebut pada klien dalam menyikapi masalahnya. Misalnya keyakinan Allah tidak membebani manusia kecuali sesuai kadar kemampuannya (AlMu'minun, 23 : 62); (Al-Baqarah, 2: 286) ; (Al An'am, 6: 152).

Kita harus yakin, bahwa Allah tidak membebani manusia di luar batas kemampuannya. Karena Dia sudah memperkirakan kemampuan masing-masing orang tidak akan sama dalam menghadapi cobaan. Yang perlu ditanamkan dalam diri kita, bahwa dibalik musibah/cobaan pasti ada hikmahnya. Hanya saja kemampuan manusia sangat terbatas untuk menangkap dan memahami apa yang ada dibalik suatu peristiwa. Hal ini menuntut kesabaran kita dalam menghadapinya, termasuk kecemasan yang diakibatkan karena ketidaksabaran kita menghadapi masalah.

\section{Hubungan Konselor dengan Klien}

Hubungan yang terjadi dalam konseling Islam antara klien dan konseling adalah uswah khasanah (teladan yang baik). Seperti yang tejadi pada waktu nabi SAW berkumpul dalam satu majelis untuk menyelesaikan permasalahan yang dihadapi oleh umatnya. Selain itu juga sebagai penyempurna akhlak.

Hubungan yang terjadi dalam konseling Islam adalah keteladanan dari konselor terhadap kliennya. Terlebih dahulu konselor harus memahami diri mereka sediri sebelum memahami dunia klien, agar dalam proses konseling tidak terjadi salah persepsi atau salah paham terhadap permasalahan yang diajukan klien.

\section{Teknik dan Metode}

Tehnik yang bisa digunakan oleh konselor muslim dalam proses konseling juga tidak jauh berbeda ketika Nabi SAW melaksanakan dakwah, yaitu bil hikmah, mauidloh khasanah dan mujadalah. Sedangkan metode yang digunakan juga tetap mengacu pada hadits: Barang siapa melihat kemungkaran maka rubahlah dengan tangannya, jika tidak mampu maka rubahlah dengan lisanmu, jika tidak mampu maka rubahlah dengan hatimu. Itulah selemah-lemahnya iman.

\section{Peran dan Fungsi konselor}

Konselor dalam konseling Islam bisa berperan sebagai guru, mitra/sahabat untuk bertukar pikiran, orang tua dan model. Sehingga sesuai dengan tujuan konseling, yaitu mengembalikan fungsi iman sebagai penentu dalam mencapai kebahagiaan hidup di dunia dan di akhirat.

Oleh karena itu, syarat sebagai konselor muslim harus dipenuhi, yaitu selain menguasai dan memahami teknik dan pendekatan konseling secara umum, juga harus memahami tentang Islam itu sendiri.

Dalam konseling Islam, kita tidak bisa lepas dari konseling secara umum. Untuk menerapkan konseling dalam Islam, mau tidak mau kita harus mengacu kepada unsur-unsur konseling pada umumnya.

\section{TUNTUTAN AKAN KONSELING RELE- GIUS DI MASA DEPAN}

Pembicaraan konseling dari perspektif Islam di atas adalah jawaban terhadap tuntutan akan konseling relegius di masa depan. Perkembangan konseling religius ini dapat dilihat dari hasil penelitian Chalfant dan Heller pada tahun 1990, sebagaimana dikutip oleh Gania (1994: 396) dalam Abdul Hayat (2008) 
menyatakan bahwa sekitar 40 persen orang yang mengalami kegelisahan jiwa lebih suka pergi meminta bantuan kepada agamawan. Lovinger dan Worthington (dalam Keating dan Fretz, 1990: 293) seperti dikutip oleh Abdul Hayat (2008) menyatakan bahwa klien yang agamis memandang negatif terhadap konselor yang bersikap sekuler, seringkali mereka menolak dan bahkan menghentikan terapi secara dini.

Oleh sebab itu, dalam kacamata agama khususnya Islam seorang konselor perlu memperhatikan nilai-nilai agama yang dianut klien. Hal itu perlu dipertimbangkan konselor dalam memberikan layanan konseling, sebab terutama klien yang fanatik dengan ajaran agamanya mungkin sangat yakin dengan pemecahan masalah pribadinya melalui nilainilai ajaran agamanya. Seperti dikemukakan oleh Bishop (1992:179) bahwa nilai-nilai agama (religius values) penting untuk dipertimbangkan oleh konselor dalam proses konseling, agar proses konseling terlaksana secara efektif.

Berkembangnya kecenderungan sebagian masyarakat dalam mengatasi permasalahan kejiwaan mereka untuk meminta bantuan kepada para agamawan itu telah terjadi di dunia barat yang sekuler. Hal serupa lebih-lebih juga terjadi di negara kita Indonesia yang masyarakatnya agamis. banyak sekali orangorang yang datang ketempat para kiai bukan untuk menanyakan masalah hukum agama, tetapi justru mengadukan permasalahan kehidupan pribadinya. Mereka meminta bantuan jalan keluar baik berupa nasehat, saran, meminta doa-doa dan didoakan untuk kesembuhan penyakit maupun keselamatan dan ketenangan jiwa. Hal ini merupakan realitas yang terjadi di masyarakat kita sekarang ini.

Sekali lagi perkembangan konseling religius memberi arti pentingnya pengembangan landasan konseling yang berwa-wasan agama, terutama dalam rangka menghadapi klien yang kuat memegang nilai-nilai ajaran agamanya. Di dunia barat hal ini berkembang dengan apa yang disebut Konseling Pastoral (konseling berdasarkan nilai-nilai Al Kitab) di kalangan umat Kristiani.

\section{SIMPULAN}

Islam selalu berorientasi pada kebaikan dan kearah perkembangan yang positif. Lalu jika Islam kita gunakan sebagai kaca mata dalam melihat konseling, maka konseling dapat diartikan sebagai bagian dari ibadah atau amal yang harus dilakukan umat muslim untuk mendapatkan kedekatan dengan khaliknya.

Konseling sebagai proses membantu individu oleh tenaga profesional yang bernama konselor, agar ia (klien) memahami diri, membuat keputusan dan pemecahan masalah, sebenarnya merupakan suruhan Allah kepada umat-Nya. Oleh sebab itu teori konseling tidak dapat dinafikan begitu saja oleh individu yang sedang mempelajari dan ingin profesional dalam bidang ini. Teori konseling yang ditambah dan diperkuat dengan perspektif Islam akan sangat membantu pekerjaan konselor guna menghadapi tuntutan klien yang agamais.

\section{DAFTAR RUJUKAN}

\section{Al Quran Nur karim}

Abdul Hayat. 2008. Konsep Konseling Berdasarkan Ayat-Ayat Al-Qur'an. Music onlinecairo.Multiply.Com.

Bishop. 1992.Religius Values as Cross-Cultural Issues in Counseling. Counseling and Values, (36): 179-191

E.A.Munro.1985. Penyuluhan (Counseling). Suatu Pendekatan berdasarkan keterampilan. Jakarta. Ghalia Indonesia.

Hansen James C. 1977. Counseling Theory and Process. Boston. Allyn and Bacon,Inc.

Muhammad Utsman Najati. 2005. Psikologi dalam Al-Quran. Bandung. Pustaka Setia.

Netty hartati, dkk. 2005. Islam dan Psikologi. Jakarta: PT Rajagrafindo Persada

Prayitno. 1998. Konseling Pancawaskita. Padang. FIP IKIP Padang.

Prayitno. 2002. Profesi dan Organisasi profesi Bimbingan dan Konseling. Direktorat 
SLTP Dirjen Dikdasmen Departeman Pendidikan Nasional

Ramayulis. 2005. Pengantar Psikologi Agama. Jakarta. Kalam Mulia

Sarlito Wirawan Sarwono. 2004. Teori-teori Psikologi Sosial. Jakarta: PT Rajagrafindo Persada

Zakiah Daradjat, dkk. 1986. Dasar-dasar Agama Islam. Jakarta. PT.Bulan Bintang. 